\title{
Analysis of the entrepreneurial characteristics of three public universities in Minas Gerais - Brazil
}

\section{Análise das características empreendedoras de três universidades públicas de Minas Gerais - Brasil}

\author{
JOÃO PAULO MOREIRA SILVA (1) \\ LILIANE DE OLIVEIRA GUIMAR ÃES (B) \\ SILVANA ALVES DA SILVA (D) \\ ADELAIDE MARIA COELHO BAETA (D)
}

\section{ABstract}

In this article we sought to analyze universities considered entrepreneurial in the context of developing countries. For this purpose, three public universities in the State of Minas Gerais were selected, which stood out in the Entrepreneurial University Ranking and in the Folha University Ranking, both of 2019. The theoretical model elaborated to guide the data analysis contemplated categories that characterize entrepreneurial universities - Technical Support, Physical Structure and Specialized Support -. Seven interviews were conducted with representatives of the Institutions directly linked to the entrepreneurial activities of IES, in addition to documentary research. The analysis of the characteristics of the public universities in Minas Gerais identified as entrepreneurial by the national rankings allowed us to verify that they present a lot of similarity in the elements that compose the categories Technical Support, Physical Structure and Specialized Support. The findings allowed the elaboration of four propositions that, if confirmed in future studies, could guide university actions with a view to strengthening the entre- 
preneurial institutional characteristics, their greater participation in the regional ecosystem and, consequently, in economic and social development.

Keywords: Entrepreneurial Universities - Entrepreneurial Characteristics - Entrepreneurship Ecosystem - Public Universities

\section{RESUMO}

Neste artigo buscou-se analisar universidades consideradas empreendedoras no contexto de países em desenvolvimento. Para tanto, foram selecionadas três universidades públicas do Estado de Minas Gerais que se destacaram no Ranking Universidade Empreendedora e no Ranking Universidade da Folha, ambos de 2019. O modelo teórico elaborado para nortear a análise de dados contemplou categorias que caracterizam as universidades empreendedoras - Apoio Técnico, Estrutura Física e Suporte Especializado -. Foram realizadas sete entrevistas com representantes das Instituições diretamente vinculados às atividades empreendedoras da IES, além de pesquisa documental. A análise das características das universidades públicas mineiras identificadas como empreendedoras pelos rankings nacionais nos permitiu constatar que elas apresentam muita similaridade nos elementos que compõem as categorias Apoio Técnico, Estrutura Física e Suporte Especializado. As constatações permitiram a elaboração de quatro proposições que, se confirmadas em estudos futuros, poderão nortear ações universitárias com vistas ao fortalecimento das características institucionais empreendedoras, à sua maior participação no ecossistema regional e, consequentemente, no desenvolvimento econômico e social.

Palavras-chave: Universidades empreendedoras - Características empreendedoras -Ecossistema empreendedor - Universidades públicas

\section{INTRODUCTION}

The concept of Entrepreneurship Ecosystem has become fundamental to the literature that seeks the understanding of entrepreneurship in a territorial context. According to Isenberg (2011), factors such as culture, support institutions, markets, public policies, financial capital and human resources are essential for the development of innovative enterprises. Science and technology institutions, 
including universities, play an increasingly relevant role in this ecosystem, given the characteristics of the Knowledge Society.

According to Etzkowitz and Zhou (2017), universities have been contributing to economic development since the 19th century, with the training of specialized professionals and the results of their research. The novelty is not only the transfer of knowledge, but the institutionalization of university-company relations with direct involvement of universities in solving community problems. These authors also point out that, as the Industrial Society is supplanted by the Knowledge Society, more and more complex scientific and technological knowledge imposes itself in practical uses, for its polyvalent nature, simultaneously theoretical and practical.

In developing countries, interactions between universities and community organizations have particularities, according to the historical and economic context that promotes them. In Brazil, as Suzigan and Albuquerque (2011) point out, the interaction between universities and companies must be understood in the context of the late development of universities and the industrialization of the country. It is important to emphasize that the new Legal Framework of Science, Technology and Innovation (Law No. 13.243/2016) and the Decree (Decree No. 9.283/2018) that regulates it propose, particularly, changes in the process of university-enterprise collaboration. Such changes will enable, for example, private organizations to retain intellectual property, coming from the results of researches developed in partnership with the public institution, and professor-researchers - who have exclusive dedication to the federal institution to which they are linked - to develop research, paid or not, in private companies, which stimulates the interaction between the public and private sectors in the promotion of open innovation.

The relevant role of universities in the process of economic, social and technological development of the regions where they are located can be recognized, but their effects cannot be considered homogenous, that is, they are dependent on their greater or lesser performance in the territory. According to Clark (2006), Etzkowitz (2004) and Tornatzky and Rideout (2014), universities that participate in local development more broadly are classified as entrepreneurial universities. 
In this article, we sought to analyze characteristics of universities considered entrepreneurial in the context of developing countries, from the point of view of the elements that characterize them. For this purpose, three public universities in the State of Minas Gerais were selected, which stood out in the Entrepreneurial University Ranking and in the University Ranking of Folha - RUF Ranking, both of 2019.

The theoretical model elaborated to guide the data analysis of this study contemplated categories that characterize entrepreneurial universities - Technical Support, Physical Structure and Specialized Support - in order to understand their forms of support and promotion of entrepreneurship and innovation, besides identifying their participation in the local entrepreneurial ecosystem (MOREIRA-SILVA et al., 2019).

This article analyzed the performance of three universities, public and entrepreneurial in the state of Minas Gerais, as well as their role in the territory where they are installed, from the categories listed. The text is subdivided as follows: after this introduction, the theoretical reference that served as the basis for the study is presented, in addition to the theoretical model used during the data analysis. Section three presents the methodology used to collect the data. The description of the cases is in section four and, finally, in section five, the results are discussed with the propositions generated from the data found. The final considerations conclude the article in section six.

\section{THEORETICAL FRAMEWORDK}

\subsection{Entrepreneurial Ecosystem: concepts and characteristics}

The role of entrepreneurship as one of the triggers of economic development in cities, regions and countries is recurrent in the literature (ISENBERG, 2011; STAM, 2008). The recognition of the importance of entrepreneurial action in the academic and business spheres has enabled the valorization of technology-based start-ups, considered key players for the viability and commercialization of innovations and technologies (DAHLSTRAND, 2007). 
The benefits coming from organizations concentrated in a certain location would be both monetary - such as reduced transportation costs - and non-monetary, such as greater access to specialized labor and greater dissemination of knowledge, which would facilitate processes of innovation and development. Additionally, studies concluded that cultural (AOYAMA, 2009; SHIROKOVA; TSUKANOVA; MORRIS, 2018; SPIGEL, 2015), social (ISENBERG, 2011; FOSTER; SHIMIZU, 2013) and infrastructural (AUDRESTSCH; BELITSKI, 2016) aspects are also extremely relevant for a region to become entrepreneurial, i.e., capable of representing a nutritious context for new business and innovation.

A certain region may have what is recognized as the "locality trace" (FELDMAN, 2014), differentiating it from others and affecting its prosperity. In the case of path dependence, the historical past of the region becomes relevant. After a large corporation is established in a given territory, for example, entrepreneurship can be fostered and the characteristics of the organizations and developments, based on the dissemination of knowledge, can spread throughout the locality, becoming "a blessing or a curse for the entrepreneurship of a region" (AOYAMA, 2009, p. 508), since the company can foster cultural exchange and the flow of knowledge in the territory or simply offer low-skilled jobs.

More recently, the concept of Entrepreneurship Ecosystem - EE - has become critical for literature seeking to understand entrepreneurship in a territorial context (ISENBERG, 2011; SPIGEL, 2015). Isenberg (2011) postulates six domains which could stimulate and support entrepreneurship and facilitate the development of a given region - culture, support institutions, markets, public policies, financial capital, and human resources - the latter representing universities and research institutes. The domains should be analyzed from a holistic perspective, since the rate of entrepreneurship initiated in the ecosystem will occur due to the influence of all the actors that compose it (GLOBAL ENTREPRENEURSHIP INDEX - GEI, 2017; SANTOS FILHO, et al., 2019).

Still on the characteristics of entrepreneurial ecosystems, it should be noted that they have relationships with geographic space, but are not confined to it (ISENBERG, 2011), nor are they related to 
a certain size of city or state (MASON; BROWN, 2014). However, it should be noted that even though they are often recognized by the same names as their cities or territories (e.g., Israeli ecosystem, Silicon Valley) the mere attempt to replicate ecosystems is not indicated (ISENBERG, 2011).

One actor who gradually came to be included and gain relevance in entrepreneurial ecosystem models were the universities (FOSTER; SHIMIZU, 2013; SPIGEL, 2015; STAM; SPIGEL, 2016). The fact that secular universities and research institutes, combined with government investments, may influence local entrepreneurship (SAXENIAN, 1990), attracting high intellectual capital and talented people (COWLING; LEE, 2017) is not recent. However, Brazil's evaluations on this aspect are not positive, since the country has unfavorable indices regarding its human capital (GEI, 2017) and deficiencies regarding the capacity of its universities to be catalysts for entrepreneurial projects (FOSTER; SHIMIZU, 2013). Thus, it is necessary to understand in depth the role of universities in the promotion of entrepreneurial activity and innovation in the national territory.

\subsection{Entrepreneurial University}

Universities contribute to the regions where they are established in various ways, from the formation of human capital, creation and transfer of knowledge, creation of new jobs and, therefore, to economic development through the generation of new productive activities and services (FRITSCH; WYRWICH, 2018; SHIROKOVA; TSUKANOVA; MORRIS, 2018). The installation of a university institution in a certain location will have various effects. Among them are the first-order ones - gains in productivity, innovation, the establishment of new companies and greater capacity for creativity and regional sustainable development - and the second-order ones, such as job generation and increased GDP (SCHUBERT; KROLL, 2016).

This perspective on the role and contributions of university institutions in the territory where they are located is based on the assumption that they represent an important player in the dynamic context of the economy, increasingly knowledge-based, working closely with the market and governments and playing a prominent role in innovation (ETZKOWITZ; LEYDESDORFF, 2000; ETZKO- 
WITZ; ZHOU, 2017; ISENBERG, 2011). Universities are now recognized as an essential player in the flow of knowledge and regional innovation, also including the entrepreneurial aspect (CLARK, 2006; GUERRERO; URBANO, 2010).

The prominent role of universities in the process of economic, social and technological development of the regions where they are located is recognized, but it is also understood that their effects are not homogeneous, i.e., they are dependent on their greater or lesser performance in the territory. Those identified as having participation in development in a broader way are classified as Entrepreneurial Universities - EU (CLARK, 2006; ETZKOWITZ, 2004; TORNATZKY; RIDEOUT, 2014). The EU elects entrepreneurship and social and economic development as its pillars, seeking to encourage, in all areas of the university, including institutional, innovative behaviors, with a view to solving technical and social problems (CLARK, 2006).

Tornatzky and Rideout (2014) advocate that traditional universities become UEs, since they shape the environments to which they belong, as well as being shaped by them (CLARK, 2006), which facilitates the return "to the society of knowledge that originates from it" (ORTEGA, 2016, p.120). In this way, the EU will be both a producer of knowledge and a disseminator of the same knowledge (GUERRERO; URBANO, 2010). Moreover, for the generation and dissemination of knowledge to occur, the three traditional academic missions must be articulated: teaching, research and extension, and at the service of society and local development (ETZKOWITZ, 2004).

The context in which universities are inserted has also undergone changes. Both in academia and business, the discussion about entrepreneurship and innovation has resulted in the valorization of nascent companies - based on science and technology - organizations that have demonstrated speed in introducing new products in established markets and also in creating new markets through information and communication technologies. Thus, technological and high-impact entrepreneurship gains space (ISENBERG, 2011) and universities will be considered one of the necessary elements for its development (FOSTER; SHIMIZU, 2013; SPIGEL, 2015).

In the midst of these transformations, entrepreneurial education is now adopted by Higher Education Institutions - HEIs and 
is growing on a large scale in 2010 (SHIROKOVA; TSUKANOVA; MORRIS, 2018), given the evaluation that entrepreneurial education could lead to economic growth and personal development of participating individuals (LACKÉUS, 2015). This change in values and mentality has led theoreticians and entrepreneurs to consider traditional university education as outdated (ANDERSON; RONTEAU, 2017) and, specifically in the national context, based only on the training of employees (ARRUDA et al., 2015).

Thus, the courses on entrepreneurship offered by HEIs focus on active methodologies, with emphasis on the development of projects and knowledge about management, which can help in the development of entrepreneurial mindset and behavior (NABI et al., 2017) and contribute to the growth and better performance of enterprises arising within universities (GANOTAKIS, 2012; MACHADO, 2018). Lackéus (2015), however, emphasizes that entrepreneurial education at the university level privileges an education on entrepreneurship theoretical knowledge that seeks a general perception on the subject, as disciplines - and not for entrepreneurship - focused on knowledge and skills needed for the process of entrepreneurship. However, it is possible that universities offer their educational services in another way, through entrepreneurship, in programs that invest on the development of knowledge, skills and entrepreneurial attitudes.

This perspective is in line with the suggestion of Rasmussen and Sorheim (2006), who emphasize that to offer entrepreneurial training that generates socioeconomic returns, it is necessary to use a wide range of activities and resources. Different methodologies, such as disciplines in classical format and activities in different environments and with practical aspect are also ways of seeking the complementarity of teaching strategies (RIBEIRO; UECHI; PLONSKI, 2018) for an effective entrepreneurial education.

In parallel with entrepreneurial teaching, entrepreneurial universities should provide students with practices and events that connect them to the external environment (INÁCIO JÚNIOR et al., 2016). Many of these actions, such as business plan competitions, lectures, events, consulting and mentoring, carried out by teachers and external agents are activities practiced by entrepreneurship centers (RICE et al., 2014). Currently, actions that foster the con- 
nection between universities, students and entrepreneurship can be visualized in different ways, such as entrepreneurial centers and hackatons, events that seek to make the university entrepreneurial environment more vibrant, through activities and tasks guided by problem solving (RIBEIRO; UECHI; PLONSKI, 2018).

The promotion of events that integrate students to incubators or technology parks, as well as the training of companies installed in these environments, indicate the relational dynamics between the actions to promote entrepreneurship of entrepreneurial universities (TORNATZKY; RIDEOUT, 2014). For Etzkowitz (2013), the transition from traditional education to that which seeks to generate new organizations is a complex process, due to the fact that entrepreneurial activities commonly occur in academic contexts different from the traditional educational context of universities. The formation of qualified professionals and the dissemination of research, for example, are actions with a traditional profile, engendered in the classroom. Essentially entrepreneurial in nature, are activities such as patenting and licensing, formation of spin-offs and the creation of a technology park (PHILPOTT et al., 2011).

The incubators are recognized by students as the second most important action in supporting university entrepreneurship (SERVIÇO DE APOIO ÀS MICRO E PEQUENAS COMPRESAS DE MINAS GERAIS - SEBRAE, 2016), and represent an important mechanism to foster entrepreneurship that emerges from the academy (ETZKOWITZ, 2013); SANTOS; FILHO, 2014; SILVA; BAÊTA; OLIVEIRA, 2016), enhancing, by the external public, the image of HEI (CHAIS; MACHADO, 2015; FERREIRA et al., 2012). The incubated companies may be housed by Technology Parks, which, like the incubators, are considered one of the symbol structures of universities that interact with government and industry (ETZKOWITZ; ZHOU, 2017; FIGLIOLI; PORTO, 2011; RICE et al., 2014.). Moreover, in general, the parks facilitate the transfer of knowledge, foster the creation and strengthening of technology-based companies, tend to increase culture and entrepreneurial activity and, finally, contribute to the generation of employment and income (VEDOVELLO; JUDICE; MACULAN, 2002). 


\subsection{Entrepreneurial Universities and the national context}

It is important to emphasize that reservations should be made regarding the possibility of a university becoming an entrepreneurial university and, therefore, having greater interaction with the environment around it. First, for the transformation to occur, several historical barriers must be overcome, such as inertia and resistance to change, typical of bureaucratic organizations and, at the same time, adopt new standards of recognition and reward for academic-entrepreneurs (KIRBY, 2006; TSENG; HUANG; CHEN, 2018).

In addition, changes in the university's modus operandi so that it acquires entrepreneurial characteristics are difficult to acquire and maintain. Aspects such as spreading values related to entrepreneurship among the different departments of the university, maintaining an integrated entrepreneurial culture among the various university sectors - a culture usually restricted to certain projects and departments - (CLARK, 2006); developing leaderships committed to innovation objectives (TORNATZY; RIDEOUT, 2014) and, finally, establishing more permanent and close relations with industry and government, while maintaining the institution's independence (ETZKOWITZ, 2004) are challenges to be overcome. The necessary elements for the constitution of an EU, mentioned above, demonstrate and reinforce the perspective that these actors will not only promote actions aimed at entrepreneurship and innovation, but will adopt administrative measures to facilitate the operationalization of these processes, including the development of a market vision (GUERRERO; URBANO, 2010) and closer interaction with external actors such as industry and government (TORNATZKY; RIDEOUT, 2014).

However, in Brazil, despite the recognition that universities are prominent in knowledge creation (CHAIS; MACHADO, 2015), there still seems to be little integration with other organizations in the market, making it difficult to disseminate knowledge and generate innovations. The lack of cooperation between universities and entrepreneurs represents precisely the main problem of the national entrepreneurial ecosystem (INÁCIO JÚNIOR et al., 2016), which occupies the 74th position in the field of university-enterprise collaboration and society (WORLD ECONOMIC FORUM - WEF, 2019). However, responsibility for the few joint projects between 
universities and the private sector cannot be attributed solely to the academy segment. Paranhos, Hasenclever and Perin (2018, p. 21) point out that the low participation of universities in business innovations also occurs "due to the lack of innovation in the Brazilian business sector", which reduces the possibility of partnerships between companies and universities.

It is clear then that, in the Brazilian case, universities still face several challenges for their transformation into entrepreneurial universities, both of internal character and those related to tradition and national culture. Those that manage to establish links with the environment, government and industry, still face, many times, bureaucratic limitations for processing knowledge transfer procedures, as well as lack of appreciation of the academic body that develops actions of entrepreneurship (KIRBY, 2006; MOREIRA-SILVA et al., 2019) and absence of internal policies for prospecting interested in the commercialization of technologies developed at the university (DINIZ et al., 2020; PARANHOS et al., 2018).

\subsection{Theoretical model}

The theoretical model designed to guide the data analysis of this research was based on an extensive review of the literature on the Entrepreneurial Ecosystem - EE and Entrepreneurial Universities - EU. The model initially sought to integrate elements that characterize entrepreneurial universities and understand their ways of supporting and fostering entrepreneurship and innovation, in addition to identifying their participation in the local entrepreneurial ecosystem. The model was created in order to also approach the student entrepreneur (MOREIRA-SILVA et al., 2019), however only the institutional aspect of universities was the object of this study.

The three categories defined for analysis of university institutions were obtained and adapted from Moreira-Silva et al. (2019). The first category, called Technical Support, considers the activities of education and training in entrepreneurship in the curriculum or extra curriculum (INÁCIO JÚNIOR et al., 2016; RIBEIRO; UECHI; PLONSKI, 2018; TORNATZKY; RIDEOUT, 2014). The extra-class activities are located in the second category, Specialized Support, understood as mentoring, consulting, events, lectures or entrepre- 
neurial competitions (ETZKOWITZ, 2004; RICE et al., 2014; TORNATZKY; RIDEOUT, 2014). Finally, there is the category Physical Structure, understood as the university structures to support entrepreneurs during their entrepreneurial trajectory. This category includes incubators, open laboratories, coworkings and technology parks (ARRUDA et al., 2015; ETZKOWITZ, 2004; FERREIRA et al., 2012; INÁCIO JÚNIOR et al., 2016; VEDOVELLO; JUDICE; MACULAN, 2002). The interaction of the three categories of entrepreneurship in universities is related to the ecosystem around them, promoting new ventures, as shown in Figure 1.

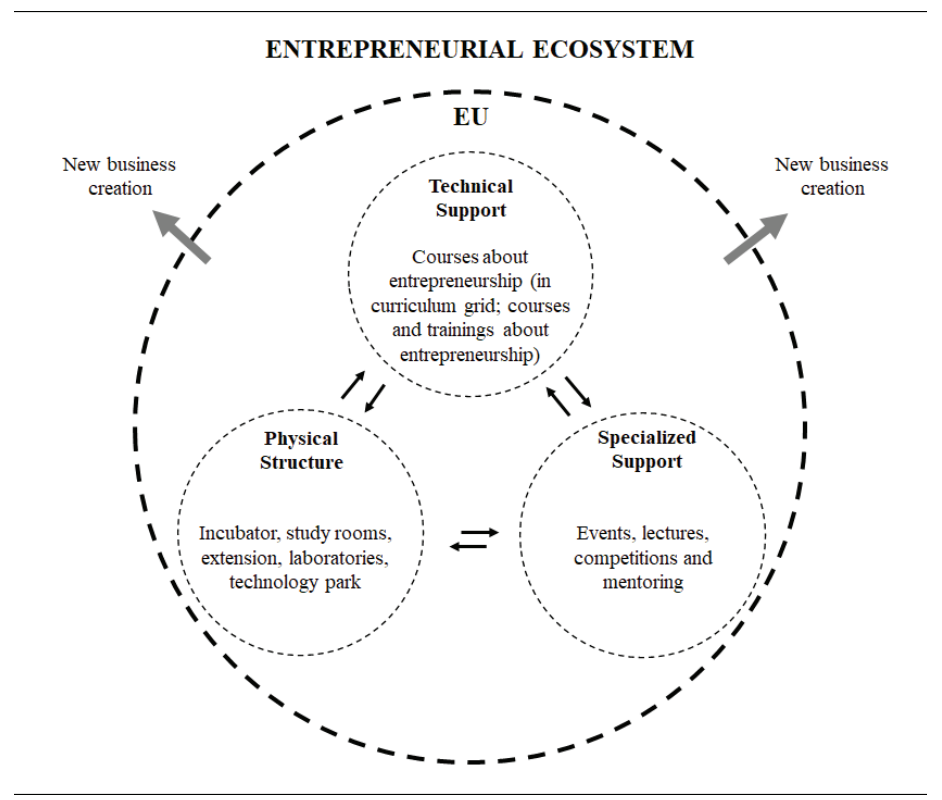

Figure 1 - Proposed theoretical model

Source: authors (2020)

\section{Methodology}

The approach used in this study was of a qualitative nature, an alternative to quantitative and monocratic research in the field of entrepreneurship (SUDDABY; BRUTON; SI, 2015), through the comparative case study method (YIN, 2005). A case study is defined as an analysis of specific social phenomena, at a given time and 
location (RAGIN; BECKER, 1992), proper for the understanding of the phenomenon in a holistic and in-depth manner, with interest also in the context in which the researched actors act (YIN, 2005).

Multiple cases were used, represented by three university institutions and their programs to promote entrepreneurship and innovation. Multiple cases, by definition, make it possible to compare the cases studied not by a sample logic, but through analytical replication, integrating robust and convincing data (YIN, 2005). The universities selected as research objects are located in the State of Minas Gerais and were chosen from two rankings published by agents external to the institutions, in which their competencies in innovation and entrepreneurship were evaluated. The three universities are among the best and most entrepreneurial universities in the state and the criteria used are in Table 1.

As highlighted, the universities researched operate in Minas Gerais, in three distinct state planning regions - South, Zona da Mata and Central (GOVERNMENT OF THE STATE OF MINAS GERAIS, 2020). In each of the institutions, their activities to foster entrepreneurship and innovation were analyzed based on the proposed theoretical model, considering the categories Technical Support; Physical Structure and Specialized Support.

Highlighting the qualitative nature of the research, the data collection tools used translate qualitative data, such as in-depth interview (GASKELL, 2003; EISENHARDT; GRABNER, 2007) and documentary research (YIN, 2005). Seven in-depth interviews were conducted with coordinators, directors and a former coordinator of university structures and programs directly linked to actions to encourage entrepreneurship and innovation at universities - see Table 2 - using a semi-structured interview script. In one of the universities, the interviews were carried out in person, but due to the measures of circulation restriction sanctioned after the beginning of the Covid-19 pandemic, in the other two cases the interviews were carried out by videoconference. From the transcription and reading of the interviews, a corpus of research was built, initial phase of content analysis (BARDIN, 2011). The seven interviews, documents, ordinances, advertising texts, promotional programs and releases of the institutions were analyzed. 
Table 1 - Rankings used, their dimensions and indicators evaluated

\begin{tabular}{|c|c|c|}
\hline Ranking & Dimensions & Indicators \\
\hline \multirow{16}{*}{$\begin{array}{l}\text { Entrepreneurial } \\
\text { University }\end{array}$} & \multirow{3}{*}{ Entrepreneurial culture } & Student entrepreneurial posture \\
\hline & & Entrepreneurial teaching posture \\
\hline & & Curriculum evaluation \\
\hline & \multirow{3}{*}{ Extension } & Networks \\
\hline & & Extension projects \\
\hline & & Altimetry \\
\hline & \multirow{3}{*}{ Innovation } & Search \\
\hline & & Patent \\
\hline & & Proximity HEI-Market \\
\hline & \multirow{3}{*}{ Internationalization } & Exchanges \\
\hline & & Partnership with foreign universities \\
\hline & & Research in international collaboration \\
\hline & \multirow{2}{*}{ Infrastructure } & Infrastructure quality \\
\hline & & Technology Park \\
\hline & \multirow{2}{*}{ Financial Capital } & Budget \\
\hline & & Endowment \\
\hline \multirow{18}{*}{$\begin{array}{l}\text { University Ranking } \\
\text { Folha }\end{array}$} & \multirow{9}{*}{ Search } & Total publications \\
\hline & & Total quotations \\
\hline & & Citations by publication \\
\hline & & Publications by faculty \\
\hline & & Quotes by teacher \\
\hline & & Publications in national magazines \\
\hline & & Resources received per institution \\
\hline & & CNPq Scholars \\
\hline & & Thesis \\
\hline & \multirow{4}{*}{ I teach } & Opinion of higher education teachers \\
\hline & & Teachers with doctorate and master's degrees \\
\hline & & Professors in full and partial dedication \\
\hline & & Score on ENADE \\
\hline & Market & Employers' opinions on hiring preferences \\
\hline & \multirow{2}{*}{ Innovation } & Patents \\
\hline & & Partnerships with companies \\
\hline & \multirow{2}{*}{ Internationalization } & International quotations by faculty \\
\hline & & Publications in international co-authorship \\
\hline
\end{tabular}

Source: authors with data from Brasil Júnior (2019) and RUF (2019) 
Table 2 - List of interviews conducted during the survey

\begin{tabular}{|l|l|l|}
\hline Interviews & Interviewed & $\begin{array}{l}\text { Dura- } \\
\text { tion } \\
\text { Time }\end{array}$ \\
\hline Interview 01 & Former NIT Coordinator - University 01 & 01:36:00 \\
\hline Interview 02 & Director Technological Park - University 01 & 00:57:00 \\
\hline Interview 03 & Program Coordinator - University 01 & $01: 43: 00$ \\
\hline Interview 04 & Director Technological Center - University 02 & 00:48:00 \\
\hline Interview 05 & NIT Coordinator - Universidade 02 & 00:47:00 \\
\hline Interview 07 & Coordinator Incubator - University 03 & 01:11:00 \\
\hline Interview 08 & $\begin{array}{l}\text { Director in Entrepreneurship and Innovation } \\
\text { - University 03 }\end{array}$ & 01:35:00 \\
\hline
\end{tabular}

Source: authors (2020)

After the initial reading of the surveyed data, the pre-defined categories in the theoretical model were used for the construction of a preliminary analysis, aggregating the sources of the data to the above-mentioned categories. After triangulation of the data, through thematic analysis (FUSCH; NESS, 2015), the data was analyzed. Table 3 presents the documents used in this study as a secondary source.

Table 3 - List of documents used in the study

\begin{tabular}{|c|c|c|c|c|c|}
\hline Document & Description & Institution & 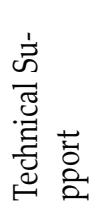 & 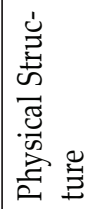 & 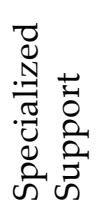 \\
\hline Doc. 01 & Institutional & Univ. 01 & $X$ & $X$ & \\
\hline Doc. 02 & Institutional 02 & Univ. 01 & $X$ & $X$ & \\
\hline Doc. 03 & Institutional - NIT & Univ. 01 & & $X$ & $x$ \\
\hline Doc. 04 & Institutional - Technology Park & Univ. 01 & & $X$ & \\
\hline Doc. 05 & Institutional - Technology Park & Univ. 02 & & $x$ & $x$ \\
\hline Doc. 06 & Institutional & Univ. 02 & $x$ & $X$ & \\
\hline Doc. 07 & Institutional 02 & Univ. 02 & & $x$ & \\
\hline
\end{tabular}




\begin{tabular}{|l|l|l|l|l|l|}
\hline Doc. 08 & Internal Release & Univ. 02 & & X & X \\
\hline Doc. 09 & Institutional Development Plan & Univ. 02 & X & X & X \\
\hline Doc. 10 & Internal Release 02 & Univ. 02 & & X & X \\
\hline Doc. 11 & Institutional Development Plan & Univ. 03 & X & X & X \\
\hline Doc. 12 & Institutional & Univ. 03 & X & X & \\
\hline Doc. 13 & News & Univ. 03 & & X & \\
\hline Doc. 14 & Institutional 02 & Univ. 03 & & X & X \\
\hline Doc. 15 & News & Univ. 03 & & X & \\
\hline Doc. 16 & Institutional 03 & Univ. 03 & & X & X \\
\hline Doc. 17 & Institutional 04 & Univ. 03 & & X & X \\
\hline Doc. 18 & News & Univ. 03 & X & & X \\
\hline Doc. 19 & $\begin{array}{l}\text { INPI - Results by Educational } \\
\text { Institution }\end{array}$ & $\begin{array}{l}\text { Univ. 01, 02 } \\
\text { and 03 }\end{array}$ & & X & \\
\hline Source: & & & & \\
\hline
\end{tabular}

Source: authors (2020)

\section{RESULTS}

The institution named in this research as University 01 is public and has, in general, the objective of developing, transmitting and applying knowledge in several areas, under the tripod of teaching-research-extension. It is currently considered one of the best universities in the country and is home to more than 49,000 students and more than 3,000 professors, 734 of whom are researchers of the National Council for Scientific and Technological Development - CNPq, in 4 different university campuses (Document 01). When evaluated by external actors of society, as in the University Ranking Folha - RUF in 2019, reached the rates of 31.47 in teaching, 40.27 in research and 3.53 in innovation, positioning itself in 1st, 7th and 5 th places nationally, respectively. In the State of Minas Gerais, this institution occupies the first general position. In another university ranking, whose evaluation focuses on the entrepreneurial actions practiced by the university, University 01 ranks 3rd nationally (BRASIL JÚNIOR, 2019).

The educational institution called University 02 is also public. In general, its mission is to promote teaching, research and extension, the advancement of science, innovation, technical, scientific and humanistic training of citizens so that they can face challenges 
and meet the demands of society and social inclusion (Document 09). This university is home to more than 19,000 students, of which approximately 15,000 are undergraduate students in three different campuses. In the assessment by RUF 2019, University 02 reached the rates of 29.74 in education (11th national), 37.94 in research (14th national); and 3.54 in innovation (4th national). In the state of Minas Gerais, according to the Folha de São Paulo ranking, the institution occupies the second place overall. As for its entrepreneurial characteristics, University 02 ranks 9th nationally (BRASIL JÚNIOR, 2019).

Finally, University 03, like the previous ones, is also public. Its mission is to effectively contribute to the scientific and technological development of society, through the generation, dissemination and application of knowledge, in addition to exercising social responsibility in the training of entrepreneurial and innovative professionals (Document 11). In two different campuses, the university is home to more than 8,000 students and more than 500 professors. When evaluated by RUF 2019, it reached the rates of 24.33 in education (35th national), 30.54 in research (45th national) and 3.35 in innovation (11th national). In the state of Minas Gerais, the institution occupies the tenth general place. In the Ranking of Entrepreneurial Universities in 2019, University 03 reached the 5th national place (BRAZIL JÚNIOR, 2019). In 2013, the university was awarded as the best entrepreneurial teaching institution in the country (Document 18).

In Table 4, you can see the summary of information about the three universities researched and their positions in the rankings mentioned above.

Table 4 - Characterization of the universities researched

\begin{tabular}{|l|l|l|l|l|l|}
\hline Institution & Foundation & $\begin{array}{l}\text { Number of } \\
\text { professors } \\
\text { (approx.) }\end{array}$ & $\begin{array}{l}\text { Number of } \\
\text { students } \\
\text { (approx.) }\end{array}$ & $\begin{array}{l}\text { Number of } \\
\text { courses offered } \\
\text { (undergraduate) }\end{array}$ & $\begin{array}{l}\text { Ranking } \\
\text { Position [RU- } \\
\text { F-MG] / [EU] }\end{array}$ \\
\hline University 01 & 1927 & 3.500 & 49.000 & 91 & {$[1] /[3]$} \\
\hline University 02 & 1926 & 1.286 & 19.000 & 75 & {$[2] /[9]$} \\
\hline University 03 & 1913 & 509 & 8.000 & 35 & {$[10] /[5]$} \\
\hline
\end{tabular}

Source: authors (2020) 
In order to characterize the moment experienced by the researched universities, data from the National Institute of Industrial Property - INPI (INPI, 2020) between 2000 and 2017 were used to compare the institutions in two aspects: applications for invention patents and utility models, both indicators measured by the rankings cited in the methodology and identified as activities with an entrepreneurial aspect (PHILPOTT et al., 2011). Initially, Figure 2 presents the filing of patents of invention by the researched HEIs. It can be seen that Universities 01 and 02 have results above the general average - composed of all national HEIs - for most of the period. However, when analyzing the triennium 2015-2017, it is remarkable the growth in the filing of patents of invention filed by University 03.

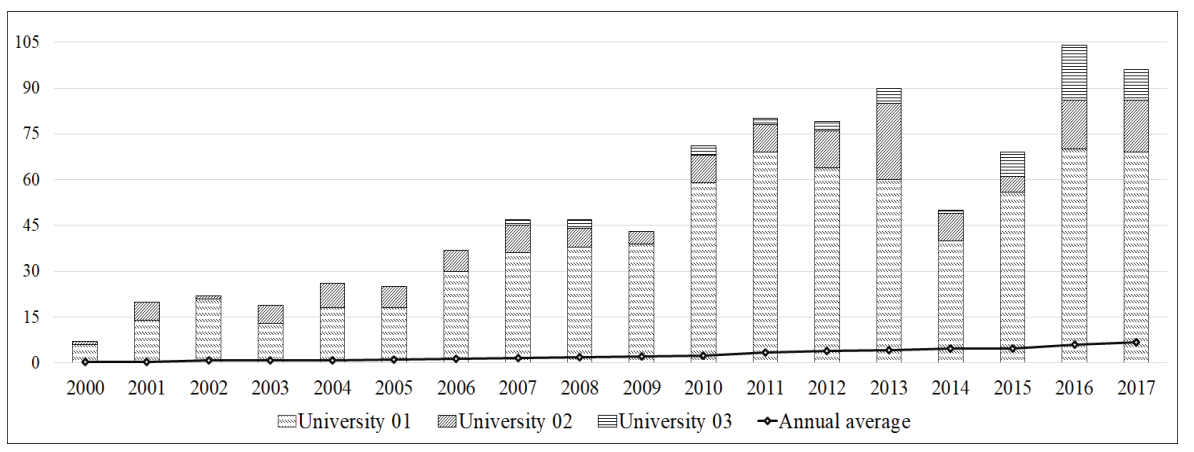

Figure 2 - Deposits of invention patents (IP) of residents by researched HEI - 2000/2017

Source: prepared based on data from INPI (2018)

The pattern of the previous graphic is repeated in Figure 3, where the deposits of utility models by HEI are presented. The utility model, different from invention patents, is recognized as a "improvement or development introduced in the object of a certain invention" (MINISTÉRIO DA CIÊNCIA, TECNOLOGIA, INOVAÇÕES E COMUNICAÇÕES - MCTIC, 2020). In the years in which universities have made some deposits, the number is above the national general average, which is below 1 deposit of utility model per year. It is also worth mentioning the predominance of 
University 02 in utility model deposits, with 35 deposits between the years 2000 and 2017.

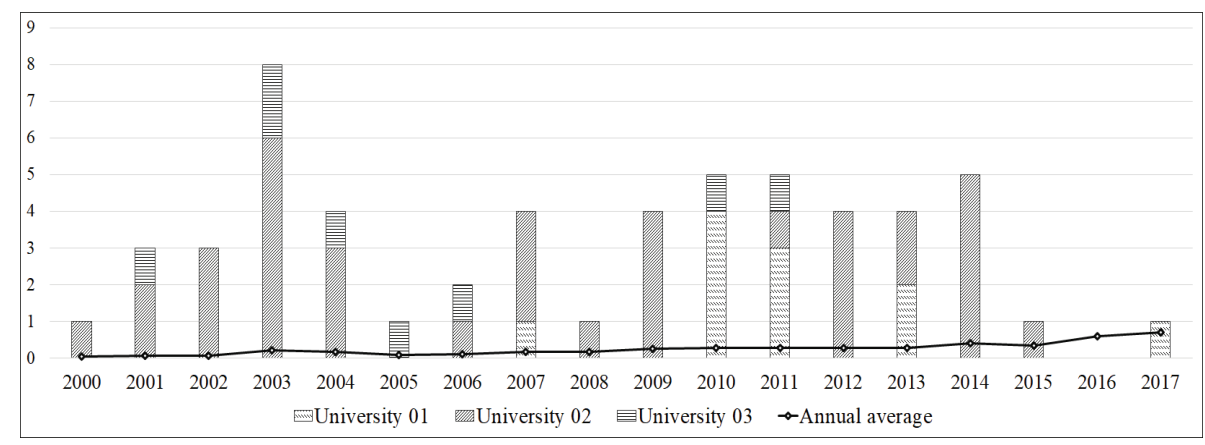

Figure 3 - Utility model deposits (UM) of residents by HEI surveyed - 2000/2017

Source: prepared based on data from INPI (2018)

The results presented by the researched institutions can be understood as a consequence of their intensive work in the production and dissemination of university knowledge. Taking as reference the theoretical model elaborated and evaluating the Physical Structure, it is highlighted that University 01, in relation to teaching, has four distinct campuses, 40 academic units and 3 special units operating in a built area of $639,777 \mathrm{~m}^{2}$ (Document 01 ). In terms of research, the university's researchers and students also have more than 600 laboratories for assistance and use in teaching and research activities (Document 01) and offers more than 150 university extension programs (Document 01).

The university also has a business incubator, created in the 90's, where more than 50 companies were graduated (Document 01) and has structure for the simultaneous incubation of 10 companies (Document 02). The actions to promote entrepreneurship and innovation are headed by the Nucleus of Technological Innovation - NIT of the university in three fronts: intellectual property, technology transfer and entrepreneurship (Document 03). The Nucleus of Entrepreneurship was formed in 2013, promoting events related to the theme, supporting entrepreneurial programs offered outside the university and offering advice to entrepreneurs. 
The NIT, in turn, has a direct link with the university's technology park. Located in an area close to the institution, the structure was inaugurated in 2012 through a partnership between University 01, State Government, City Hall, Minas Gerais State Industry Federation - FIEMG and SEBRAE. One of the goals of the park, which currently houses 22 companies and centers of technological development from the university, is precisely the strengthening of ties between university and company, seeking the generation of innovations, investments and new technology-based companies. All this support structure for entrepreneurial activities and innovation aims to contribute to the development of the regional economy (Document 04).

University 02 has three campuses and more than 600 laboratories for the various university activities (Document 05). In 2018 alone, 40 extension programs were executed (Document 06). The university also has an incubator, created in 1996, having already graduated more than 30 companies (Document 07). The incubator, as well as the actions to foster entrepreneurship and innovation, is linked to the university's technological center, which also has, among its units, a technological park.

The technology park, created in 2011, is the first technology park in Minas Gerais (Document 08) and was founded from a partnership between University 02, the Government of the State of Minas Gerais and the City Hall (Document 10). The park's mission is to "increase the wealth of the neighboring community" (Document 08), offering pre-incubation and incubation programs, fostering entrepreneurship through junior companies and support to resident companies (Document 07). The technology park also has a program for the interaction of junior companies, promoting the exchange of experiences among 42 junior companies in the university (Document 08).

University 03, in turn, operates in two campuses and has more than 350 laboratories for student use (Document 11). The university's business incubator has already graduated more than 40 companies, launching more than 150 products in the market (Document 12). Being a centenary university and the oldest among the researched universities, University 03 reinforces its pioneerism through its Entrepreneurship Center, inaugurated around 2010 (Interview 05), 
which includes a coworking space and workstations for creative projects (Document 16).

The university's technological park, inaugurated at the end of 2012 (Document 13), currently houses three research centers, in addition to the technological incubator and the university's distance education center (Document 14). The park is currently expanding and moving the surrounding community, including the City Hall and partner companies (Document 15).

Considering the category Technical Support, it can be seen that all three universities researched have entrepreneurial training subjects in curriculum and also in extracurricular format. University 03, for example, has a complementary formation in entrepreneurship that can be taken by its students. The formation presupposes, as base, disciplines of introduction to the subject and later the possibility of the student to deepen in disciplines correlated to the area of knowledge of his graduation course (Document 17).

According to the interviewees, the extracurricular disciplines would be more in line with what is intended for the formation of the entrepreneur, i.e., appropriate to practical realities and based on teachings by projects:

You will have the issue of entrepreneurship worked through in some courses. All of them? No [...] but, to be honest, I don't believe in discipline, okay? I believe in actions that involve the learning by project - or involvement with projects - more active methodologies. Maybe the discipline is interesting there to awaken, to introduce the theme... (Interviewed 5).

[University 03] is a project box. Most [of the students] are there because of the projects. In the classroom... boring. This thing doesn't work anymore, honestly [...]. But it's not what it has in the classroom, it's what it applies. This is the best in the university. (Interviewed 7).

The offer of disciplines considered traditional is cited by program coordinators and structures to promote entrepreneurship as one of the barriers to greater student participation in programs and events organized by universities. The concern of students to be ap- 
proved in regular subjects, for example, inhibits their participation in events at University 02: "if another activity appears, he understands that it would not fit. That it will be a very hard job" (Interviewed $5)$. What can be even more dramatic in cases of longer programs, as in the case of University 01: "in some moments, we had programs that lasted a little longer and the student would say: 'look, I have a test.' And then the engagement stopped...» (Interviewed 1). Interviewee 7 summarizes the difficult questioning and clash between the traditional university disciplines and the extracurricular ones:

Does it give you the option to do entrepreneurship? Or does it make more sense for you to seek initiatives outside the classroom, since entrepreneurship is something so different from what is happening in there? [...] Or both? [...] I, particularly, think it has to have both. (Interviewed 3).

Analyzing the data collected from the three universities, it can be seen that the extracurricular activities are linked to the events and programs to promote entrepreneurship that take place under the aegis of the centers of entrepreneurship and innovation in each of the institutions. The events, however, can be observed from the theoretical model in the category called Specialized Support, treated below.

About the events about innovation and entrepreneurship, it is observed that they are frequent. According to the interviewees, the students "have hundreds (sic) things to do" (Interviewee 5), since "today you stumble, you are in a pre-acceleration program" (Interviewee 3 ). And the great content and options to the students began to become a concern of the interviewees. The coordinators, in this way, sought alternatives for aggregating the events, so that they could occur in a systematized way, grouping the various programs within a general orientation of university entrepreneurial trajectory. It was the objective, for example, of one of the coordinators of University 01: "to create a way in which the programs would not be cannibalized, would not overlap [...] and would make sense in the student's journey" (Interviewee 1).

In the case of University 03, for example, a new program was recently created to help students who were in the early stages of 
their ideas: "we created an ideation program [...] a program below, because sometimes the guy disappeared between the window of pre-acceleration (more advanced stage)" (Interviewee 7). The possibility of creating new programs that help and integrate existing ones demonstrates the flexibility of the initiatives to promote entrepreneurship in the researched institutions. Interviewee 1 recalls that he was able to follow, at University 1, a competition being won by a group from a department with no tradition of participating in events organized by the university. This department began to replicate the knowledge acquired during the competition and won the competition again the following year: "a wonderful experience of activating the ecosystem [...] only needed one spark" (Interviewee 1).

Another action carried out by university programs to foster entrepreneurship and innovation are the mentories, which also make up the specialized support and are mentioned as one of the important aspects of the university entrepreneurial journey (Moreira-Silva et al., 2019). One of the strategies created at University 03 is the use of mentoring as a link between entrepreneurs in training and new participants in the events. Students who would like to undertake, develop good projects and show interest in the topic, are invited to participate in subsequent events as mentors, which ultimately increases integration among the different students and strengthens the community: "they know all the attention and guidance they have had $[. .$.$] is to give back to the university, create a virtuous circle"$ (Interviewee 7).

Counseling through advisory and consulting services also occurs. In the case of University 02, in 2019, 101 hours of consultancy were provided to companies that have links with the technology park. The totality of these companies received at least one consultancy on themes that vary between recruitment and selection, marketing and sales, finance and leadership (Document 08). Table 5 below shows some examples taken from the interviews and the respective categories worked on in the theoretical model. 


\section{Table 5 - Examples taken from the interviews and the categories of the theoretical model}

\begin{tabular}{|c|c|}
\hline Categories & Examples extracted from the data \\
\hline \multirow{4}{*}{ Technical Support } & $\begin{array}{l}\text { "Here nobody cares about what is different; they only care about } \\
\text { the usual, same stuff. I show you the discipline, you write it down } \\
\text { in your notebook, I give you an exercise list, you go to the monito- } \\
\text { ring and I apply the test". [U1] }\end{array}$ \\
\hline & $\begin{array}{l}\text { "Traditional disciplines... training many professionals to work in } \\
\text { large companies". [U2] }\end{array}$ \\
\hline & $\begin{array}{l}\text { "Not only work research, research, research... [...] "It's important to do } \\
\text { research, but what is it generating? Numbers for the university?" [U2] }\end{array}$ \\
\hline & $\begin{array}{l}\text { "[...] is to form that mindset. For example, I take an extension, a } \\
\text { complementary formation or even an optional subject, where he is } \\
\text { there because he wants to be there, it is not mandatory". [U3] }\end{array}$ \\
\hline \multirow{3}{*}{$\begin{array}{l}\text { Specialized Su- } \\
\text { pport }\end{array}$} & $\begin{array}{l}\text { "You have the question of entrepreneurship not in the form of a } \\
\text { discipline, but in the cross-curricular form, in which you work on } \\
\text { product development, business plans, do feasibility analysis in some } \\
\text { courses". [U2] }\end{array}$ \\
\hline & $\begin{array}{l}\text { "That's what I told you about the importance of the program. If } \\
\text { you give it to the student there, a subject, he talks like this: 'ah, but } \\
\text { I have another one' [...] Actually, there [at the event] the guys were } \\
\text { there, thinking about a little idea two weeks ago, they saw the event } \\
\text { and said: "oops! Go test it, go, let's go". [U1] }\end{array}$ \\
\hline & $\begin{array}{l}\text { "We had a company that had come with proposals, it had already } \\
\text { cemented in the incubation programs, hired startup - more than one } \\
\text {-, already sat down for us to plan a hackathon together, sponsored } \\
\text {..." [U3] }\end{array}$ \\
\hline \multirow{4}{*}{ Physical Structure } & $\begin{array}{l}\text { "The moment is very good, because the rectory likes the idea and } \\
\text { wants to support it, and NIT is doing a nice thing [...] people from } \\
\text { the pro-rectorate are excited". [U1] }\end{array}$ \\
\hline & $\begin{array}{l}\text { "Take agile methodologies into the classrooms, a practical experien- } \\
\text { ce and a way to spread what is done in the park". [U2] }\end{array}$ \\
\hline & $\begin{array}{l}\text { "Today our Technology Park is supported by the university. Not } \\
\text { today, since always". [U2] }\end{array}$ \\
\hline & $\begin{array}{l}\text { "I say The Entrepreneurship Center is really a heat center where } \\
\text { you have to put in a lot of energy, you know? It's really a commu- } \\
\text { nity". [U3] }\end{array}$ \\
\hline
\end{tabular}

Source: authors (2020) 
The interviewees also showed some concerns about the institutionalization of the mentioned entrepreneurial actions. It was identified that, among the three universities researched, only some departments and/or institutes are more active on fomenting the entrepreneurial culture and propose actions that strengthen the relation of the university with companies. In all the researched cases, the departments that have actions of greater entrepreneurial impact are those linked to applied research.

Moreover, even the recognition of the performance of these outstanding departments and institutes does not let the coordinators cease to seek the institutionalization of actions to foster entrepreneurship and innovation. Once these actions occur together, it is concluded that the results of the universities with these actions can be even more effective, since they can reach departments and institutes not yet contemplated and can minimize the overlap of programs and events, which can overload students.

We have been trying to unify, to centralize, so that it doesn't happen loose... that we have seen with the separate movements... so it is to centralize here at the agency. So that nothing overlaps (Interviewee 4).

Today we are more engaged in attracting an audience beyond the hardware. Because students are starting to come from the same courses: Mechanics, Electrical, Control and Automation, Electronics... and this is very dominated for us now. We want to attract students from other courses: Biology, Chemistry, Physics... (Interviewed 7).

However, the obstacle for the institutionalization to occur and embrace the other sectors of the university is the recognition that, until the present moment, the actions to promote entrepreneurship and innovation happen from personal relationships, among teachers, coordinators and interested in university actions. As the interviewees postulate, "among individuals" (Interviewee 7), or "among CPFs" (Interviewee 5).

If you serve the entrepreneur who is filling out the program form at 11 o'clock at night, you do it as an Individual. You are not doing it as a professional. (Interviewed 7). 
As mentioned, the institutionalization, or the search for a greater participation of other actors in the actions to promote entrepreneurship - such as departments and institutes with no previous history of participation - is related to the perception of the own interviewees that the current moment is propitious for entrepreneurship and the university-company relationship to be strengthened and promoted throughout the university. This analysis is based on the perception that university-company interaction has evolved in recent years and also on the strong support from top management for actions to take place, despite not institutionalizing them.

According to the interviewees, conflicts between groups that see the university-enterprise relationship as beneficial and others that perceive this interaction from a negative perspective no longer occur as they once did. The performance of these groups "is not as great" (Interviewee 7), "much less than it was 10, 12 years ago" (Interviewee 3) or they "have no more courage to manifest themselves" (Interviewee 5), due to the results achieved by the actions of the universities themselves.

According to the interviewees, the perception that there are fewer conflicts about the university-enterprise relationship has the seal of the universities' higher administrations. The university leaders began to recognize the importance of initiatives to promote entrepreneurship and innovation and, especially in Universities 02 and 03 , to act more closely to the programs. The coordinators are now facing "the best of the worlds" (Interviewee 7), and understand that institutional support "makes the work much easier" (Interviewee 5). The senior management has become more interested in the actions and programs, from the request for reports on the programs' activities to a greater commitment to the acquisition of public and private resources.

The greater proximity between university and company is also valued when discussing the scarcity of resources. Due to the context of financial crisis at both state and federal levels in Brazil, respondents recognize that the current moment is not as fruitful in terms of financial support as before, so partnerships with the private sector become even more interesting and can help in providing resources previously offered by public authorities. 


\section{Discussion}

During the survey, it was found that the universities researched have systematized structures and programs, which comprehensively embrace the possibilities of the university entrepreneurial journey. Moreover, in general, the structures of the programs are flexible, which allows improvements and unfoldings to be carried out in case of need, or events to be raised to the category of subjects, for example. Relating the three categories that integrate the theoretical model used - physical structure, technical support and specialized support - it can be seen that there is similarity among universities, which have, as a rule, structures and offers of equivalent programs and events. Figure 4, below, demonstrates the result of the data analysis.

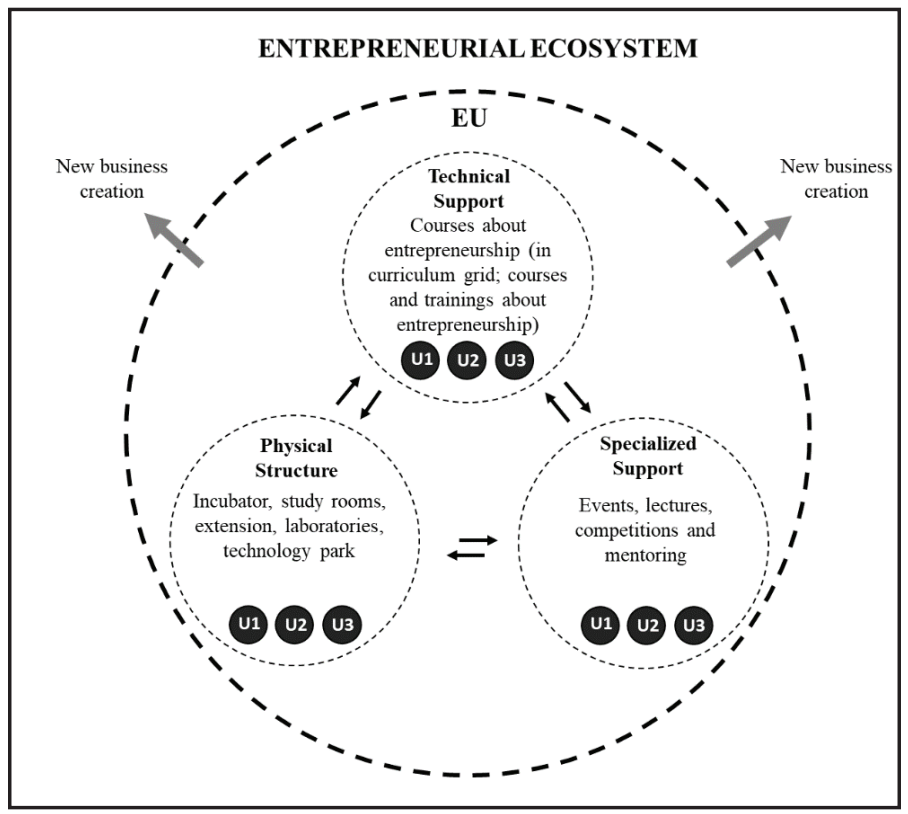

Figure 4 - Theoretical model superimposed on the researched universities Source: authors (2020)

The universities researched have demonstrated a robust Physical Structure, invariably composed of several programs to foster and support entrepreneurship and science and technology, from technology transfer offices - which transform research and publica- 
tions into innovations (ETZKOWITZ, 2004; PHILPOTT et al., 2011) to incubators and technology parks. The latter, symbol structures of the entrepreneurial university, are important in generating enterprises that have a connection with government and industry (ETZKOWITZ, ZHOU, 2017), host innovative companies (RICE et al., 2014) and foster the entrepreneurial culture in the environments investigated (ETZKOWITZ, 2013) which may contribute to the socioeconomic development of the local ecosystem, one of the major objectives of the entrepreneurial university (CLARK, 2006; ETZKOWITZ, 2004). Thus, from the structures of promotion of entrepreneurial activity and its relationship with universities, we have the first proposition:

Proposition 01: in universities considered entrepreneurial, different physical structures are created to support and foster entrepreneurship.

In the case of Technical Support, the interviewees emphasized their concern with the use of the disciplines in curricula and their little contribution to the development of entrepreneurial skills, defending their use for the transfer of general and introductory knowledge. At this time, the criticism about the university training in entrepreneurship is resumed (ANDERSON; RONTEAU, 2017) and based on a perspective of training employees for large companies (ARRUDA et al., 2015). Thus, the literature in the area points to the need for an education that is focused on practical aspects, based on projects, and that is guided by a concept that seeks the development of knowledge, skills and entrepreneurial attitudes (LACKÉUS, 2015). According to the interviewees, the methodology of more applied character of the entrepreneurship disciplines could be used in extracurricular disciplines, where its optional and practical character stand out. In general, both formats should be used, in a complementary way, for the best conduction of training for entrepreneurship (RIBEIRO; UECHI; PLONSKI, 2018). The analysis of the Technical Support category in the three HEI in the State of Minas Gerais considered the most entrepreneurial allowed the elaboration of the following proposition:

Proposition 02: in universities considered entrepreneurial, the offer of subjects - with themes and contents on entrepreneurship - is made both in regular courses and extracurricular. 
As highlighted, the need for practical projects for the development of entrepreneurial education is shared by respondents, in line with the studies of Rasmussen and Sorheim (2006), which highlight the value of offering a wide range of activities and resources for the development of entrepreneurial activities. These activities can be introduced in several ways, such as events - lectures, competitions - which connect students to the external environment (INÁCIO JÚNIOR et al., 2016) and promote a network of entrepreneurial students (RICE et al., 2014), identified in this study as elements of the Specialized Support category. In addition, consulting and mentoring practices have also been identified and demonstrate the search for development in entrepreneurial students of management knowledge, in addition to contributing to strengthening ties with the external business environment (MOREIRA-SILVA et al., 2019) and the expansion of enterprises (GANOTAKIS, 2012; MACHADO, 2018). These activities are used in the universities researched and have the objective of moving the university environment, commonly making it more vibrant (RIBEIRO; UECHI; PLONSKI, 2018). This finding allows to elaborate the third proposition of this study:

Proposition 03: In universities considered entrepreneurial, support activities for entrepreneurs such as mentoring and lectures, as well as participation in events and competitions should be offered in order to promote the entrepreneurial culture and support nascent companies.

One of the points highlighted by the interviewees was the concern with the institutionalization of programs to promote entrepreneurship. As mentioned above, the greater acceptance in relation to university-company relations is propitious for the search of resources in public and private organizations that are invested in activities and actions to promote entrepreneurship. University integration within a perspective of developing entrepreneurial skills and competencies aims to include not only the departments linked to applied research, but also the other sectors of HEI (DINIZ et al. 2020). The institutionalization of university entrepreneurial actions is foreseen by Clark (2006) as one of the characteristics of an EU, where the construction of an entrepreneurial culture permeates all sectors of the educational institution, even though it is recognized 
as a complex process involving several actors (TORNATZKY; RIDEOUT, 2014).

In addition, the results also show that the interaction of research activities in entrepreneurial universities with the productive sector is now valued as an asset that helps the university in its institutional mission of training people and professionals (ETZKOWITZ, 2001), and is stimulated by top university management. From the search for the institutionalization of entrepreneurial activities and the consequent construction of a culture we have the fourth proposition:

Proposition 04: in universities considered entrepreneurial, efforts are made to define strategies for institutionalization of entrepreneurial activities, seeking to create culture and integrate departments that traditionally do not participate in events and actions of this nature.

\section{Concluding REMARKS}

The analysis of the characteristics of public universities in Minas Gerais identified as entrepreneurial by the national rankings has allowed us to see that they present much similarity in the elements that make up the categories Technical Support, Physical Structure and Specialized Support, defined in the theoretical model as fundamental dimensions to characterize HEIs that guide their performance by greater interaction with the environment and by actions that seek to transform scientific knowledge into innovations. The findings obtained from this study allowed the elaboration of four propositions that, if confirmed in future studies, could guide university decisions and actions with a view to strengthening entrepreneurial institutional characteristics, their greater participation in the regional ecosystem and, consequently, in economic and social development.

One of the limitations of this study refers to the number of cases analyzed, considering that only those universities that stood out as entrepreneurs and located in the State of Minas Gerais were analyzed. Research agendas need to be established for the analysis of the effectiveness of university management actions in terms of Technical Support, Specialized Support and Physical Structure to stimulate entrepreneurship, in order to expand knowledge in the field of studies and foster greater integration of HEIs with society. 


\section{REFERENCES}

ANDERSON, A.; RONTEAU, S. Towards an entrepreneurial theory of practice; emerging ideas for emerging economies. Journal of Entrepreneurship in Emerging Economies, v. 9, n. 3, p. 110120. 2017. Disponível em: http://www.emeraldinsight.com/doi/abs/10.1108/JEEE-12-2016-0054

ARRUDA, C.; NOGUEIRA, V. S.; COZZI, A.; COSTA, V. The brazilian entrepreneurial ecosystem of startups: na analysis of entrepreneurship determinants in Brazil and the perceptions around the brazilian regulatory framework. In: Entrepreneurship in BRICS, 2015. p. 9-25. Disponível em: https://link.springer.com/chapter/10.1007/978-3-319-11412-5_2

AUDRETSCH, D. B.; BELITSKI, M. Entrepreneurial ecosystems in cities: establishing the framework conditions. Journal of Technology Transfer, p. 1-11. 2016.

AOYAMA, Y. Entrepreneurship and regional culture: the case of Hamamatsu and Kyoto, Japan. Regional Studies, v. 43, n. 3, p. 495-512. 2009.

BARDIN, L. Organização da análise In: Análise de conteúdo. Lisboa: Edições 70, 2011. p. 125-170.

BRASIL. Lei no 13.243, de 11 de janeiro de 2016. Dispõe sobre estímulos ao desenvolvimento científico, à pesquisa, à capacitação científica e tecnológica e à inovação e altera a Lei ํㅜำ 10.973, de 2 de dezembro de 2004, a Lei no 6.815, de 19 de agosto de 1980, a Lei $\mathrm{n}^{\circ}$ 8.666, de 21 de junho de 1993, a Lei oㅜ 12.462, de 4 de agosto de 2011, a Lei oㅜ 8.745, de 9 de dezembro de 1993, a Lei no 8.958, de 20 de dezembro de 1994, a Lei no 8.010, de 29 de março de 1990, a Lei $\mathrm{n}^{\mathrm{o}}$ 8.032, de 12 de abril de 1990, e a Lei no 12.772, de 28 de dezembro de 2012, nos termos da Emenda Constitucional no 85, de 26 de fevereiro de 2015.

. Decreto $n^{\circ}$ 9.283, de 7 de fevereiro de 2018. Regulamenta a Lei oํ 10.973, de 2 de

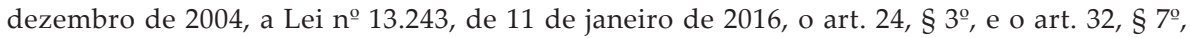
da Lei $n^{\circ}$ 8.666, de 21 de junho de 1993, o art. $1^{\circ}$ da Lei $n^{\circ}$ 8.010, de 29 de março de 1990, e o art. $2^{\circ}$, caput, inciso I, alínea "g", da Lei no 8.032, de 12 de abril de 1990, e altera o Decreto no 6.759 , de 5 de fevereiro de 2009, para estabelecer medidas de incentivo à inovação e à pesquisa científica e tecnológica no ambiente produtivo, com vistas à capacitação tecnológica, ao alcance da autonomia tecnológica e ao desenvolvimento do sistema produtivo nacional e regional. Diário Oficial da União, Brasília, 7 de fev. 2018.

BRASIL JÚNIOR. Universidades Empreendedoras 2019. 2019. Disponível em: https://brasiljunior. org.br/conteudos/ranking-de-universidades-empreendedoras-2019

CHAIS, C.; MACHADO, C. Universidade empreendedora: a ótica dos empresários sobre o posicionamento empreendedor da universidade na contribuição para o desenvolvimento regional. Revista Gestão Universitária na América Latina, v. 8, n. 4, p. 57-76. 2015. Disponível em: http://www.redalyc.org/pdf/3193/319343257005.pdf

CLARK, B. R. Pursuing the entrepreneurial university. In: Innovation and entrepreneurialism in the university. Porto Alegre: EDIPCURS, 2006. p. 15-27. Disponível em: http://www.pucrs. br/wp-content/uploads/2016/02/inovacaoeempreendedorismo.pdf

COWLING, M.; LEE, N. How entrepreneurship, culture and universities influence the geographical distribution of UK talent and city growth. Journal of Management Development, v. 36, n. 2, p. 178-195. 2017. Disponível em: http://www.emeraldinsight.com/doi/abs/10.1108/ JMD-03-2016-0043 
DAHLSTRAND, A. L. Technology-based entrepreneurship and regional development: the case of Sweden. European Business Review, v. 19, n.5, p. 373-384. 2007. Disponível em: http:// www.emeraldinsight.com/doi/abs/10.1108/09555340710818969

DINIZ, A. M.; MENDONÇA, F. M.; SIQUEIRA, P. H. L.; SANTOS, M. G. Transferência de conhecimento entre universidade e empresa (U-E): influência das condições universitárias. BASE - Revista de Administração e Contabilidade da Unisinos, v. 17, n.1, p. 70-90. 2020.

EISENHARDT, K., GRAEBNER, M. Theory building from cases: opportunities and challenges. Academy of Management Journal, v. 60, n. (1), p. 25-32. 2007.

ETZKOWITZ, H.; LEYDESDORFF, L. The dynamics of innovation: from National Systems and "Mode 2" to a Triple Helix of university-industry-government relations. Research Policy, v. 29, p. 109-123. 2000. Disponível em: http://www.oni.uerj.br/media/downloads/1-s2.0S0048733399000554-main.pdf

ETZKOWITZ, H. The second academic revolution and the rise of entrepreneurial Science. IEEE Technology and Society Magazine, p. 18-29. 2001. Disponível em: http://ieeexplore.ieee. org/document/948843/

. The evolution of the entrepreneurial university. International Journal of Technology and Globalization, v. 1, n. 1, p. 64-78. 2004. Disponível em: https://www.inderscienceonline. com/doi/abs/10.1504/IJTG.2004.004551

. Anatomy of the entrepreneurial university. Social Science Information, v. 52, n. 3, p. 486-511. 2013. Disponível em: https://journals.sagepub.com/doi/abs/10.1177/0539018413485832?journalCode $=$ ssic

ETZKOWITZ, H.; ZHOU, C. Hélice tríplice: inovação e empreendedorismo universidade-indústria-governo. Estudos Avançados, v. 31, n. 90, p. 23-48. 2017.

FELDMAN, M. P. The character of innovative places: entrepreneurial strategy, economic development, and prosperity. Small Business Economics, v. 43, p. 9-20. 2014.

FERREIRA, G. C.; SORIA, A. F.; CLOSS, L. Gestão da interação universidade-empresa: o caso PUC-RS. Revista Sociedade e Estado, v. 27, n. 1, p. 79-93. 2012. Disponível em: http://www. scielo.br/scielo.php?script=sci_arttext\&pid=S0102-69922012000100006

FIGLIOLI, A.; PORTO, G. P. Financiamento de parques tecnológicos: um estudo comparativo de casos brasileiros, portugueses e espanhóis. R. Adm - Revista de Administração., v. 47, n. 1, p. 290-306. 2011.

FOSTER, G.; SHIMIZU, C. Entrepreneurial ecosystems around the globe and company growth dynamics. In: Annual Meeting of the New Champions 2013, p. 1-36. 2013. Disponível em: http:// www3.weforum.org/docs/WEF_EntrepreneurialEcosystems_Report_2013.pdf

FUSCH, P. I.; NESS, L. R. Are we there yet? Data saturation in qualitative research. The Qualitative Report, v. 20, n. 9, p. 1408-1416. 2015.

FRITSCH, M.; WYRWICH, M. Regional knowledge, entrepreneurial culture, and innovative start-ups over time and space - an empirical investigation. Small Business Economics, v. 51, n. 2, p. 337-353. 2018. Disponível em: https://link.springer.com/article/10.1007/s11187-018-0016-6 
GANOTAKIS, P. Founders' human capital and the performance of UK new technology based firms. Small Business Economics, v. 39, p. 495-515. 2012. Disponível em: https://link.springer. com/article/10.1007/s11187-010-9309-0

GASKEL, G. Entrevistas individuais e grupais. In: Pesquisa qualitativa com texto, imagem e som: um manual prático. Petrópolis: Vozes. 2003. p. 64-89.

GLOBAL ENTREPRENEURSHIP INDEX. The Global Entrepreneurship Index 2017. 2017. Disponível em: https://thegedi.org/2017-global-entrepreneurship-index/

GOVERNO DO ESTADO DE MINAS GERAIS. Dados Gerais. 2019. Disponível em: https:// www.mg.gov.br/conteudo/conheca-minas/geografia/dados-gerais

GUERRERO, M.; URBANO, D. Entrepreneurial Business Model for Classical Research University. Journal of Technology Transfer, p. 1-33. 2010.

INÁCIO JÚNIOR, E., I.; AUTIO, E.; MORINI, C.; GIMENEZ, F., A., P.; DIONISIO, E., A. Analysis of the brazilian entrepreneurial ecosystem. Desenvolvimento em Questão. v. 37, p. 5-36. Disponível em: https://www.revistas.unijui.edu.br/index.php/desenvolvimentoemquestao/ article/view/6253

INSTITUTO NACIONAL DA PROPRIEDADE INDUSTRIAL. Estatísticas. 2020. Disponível em: http://www.inpi.gov.br/sobre/estatisticas/estatisticas

ISENBERG, D. The entrepreneurship ecosystem strategy as a new paradigm for economy policy: principles for cultivating entrepreneurship. The Babsom Entrepreneurship Ecosystem Project. 2011.

KIRBY, D. A. Creating Entrepreneurial Universities in the UK: Applying Entrepreneurship Theory to Practice. Journal of Technology Transfer, v. 31, p. 599-603. 2006.

LACKÉUS, M. Entrepreneurship: what, why, when, how. OECD Entrepreneurship360 Background Paper. p. 1-45. 2015. Disponível em: https://www.oecd.org/cfe/leed/BGP_Entrepreneurship-in-Education.pdf

MACHADO, H. P. V. Crescimento de empresas na perspectiva de pequenos empreendedores de base tecnológica. RAC - Revista de Administração Contemporânea, v. 22, n. 6, p. 817-840. 2018. Disponível em: http://www.scielo.br/scielo.php?script=sci_abstract\&pi$\mathrm{d}=$ S1415-65552018000600817\&lng=pt\&nrm=iso

MASON, C.; BROWN, R. Entrepreneurial ecosystems and growth oriented entrepreneurship. In: LEED Programme and the Dutch Ministry of Economic Affairs, p. 1-30. 2014.

MINISTÉRIO DA CIÊNCIA, TECNOLOGIA, INOVAÇÕES E COMUNICAÇÕES. Notas metodológicas. 2020. Disponível em: https://www.mctic.gov.br/mctic/opencms/indicadores/ detalhe/Notas_Metodologicas/Patentes.html?searchRef=pesquisa\&tipoBusca=expressaoExata MOREIRA-SILVA, J. P.; GUIMARÃES, L. O.; INÁCIO JÚNIOR, E.; CASTRO, J. M. de. Ecossistema empreendedor: análise da contribuição de universidades na criação de empresas

de base tecnológica. In: ENCONTRO NACIONAL DA ASSOCIAÇÃO NACIONAL DE PÓS-GRADUAÇÃO E PESQUISA EM ADMINISTRAÇÃO, 2019, São Paulo. Anais eletrônicos..., São Paulo, 2019. Disponível em: http://www.anpad.org.br. 
NABI, G.; LIÑÁN, F.; FAYOLLE, A.; KRUEGER, N.; WALMSLEY, A. The impact of entrepreneurship education in higher education: a systematic review and research agenda. Academy of Management Learning \& Education, v. 16, p. 277-299. 2017.

ORTEGA, L. M. Programa empreendedorismo-escola: influenciando a universidade por meio do tripé ensino, pesquisa e extensão. RACEF - Revista de Administração, Contabilidade e Economia da Fundac, v. 7, n.1, p. 118-131.2016. Disponível em: http://www.spell.org.br/documentos/ ver/40129/programa-empreendedorismo-escola--influenciando-a-universidade-por-meio-do-tripe-ensino--pesquisa-e-extensao

PARANHOS, J.; HASENCLEVER, L.; PERIN, F. S. Abordagens teóricas sobre o relacionamento entre empresas e universidades e o cenário brasileiro. Econômicas - Niterói, v. 20, n. 1, p. 9-29. 2018.

PHILLPOTT, K.; DOOLEY, L.; O'REILLY, C.; LUPTON, G. The entrepreneurial university: examining the underlying academic tensions. Technovation, v. 31, p. 161-170. 2011. Disponível em: https://www.sciencedirect.com/science/article/pii/S0166497210001331

RAGIN, C. Introduction: cases of "what is a case?". In: What is a case? Cambridge: Cambridge University Press. 1992. p. 1-17

RANKING UNIVERSITÁRIO FOLHA - RUF. 2019. Disponível em: https://ruf.folha.uol.com. br/2019/

RASMUSSEN, E. A.; SORHEIM, R. Action-based entrepreneurship education. Technovation, v. 26, p. 185-194. 2006.

RIBEIRO, A. T. V. B.; UECHI, J. N.; PLONSKI, G. A. Building builders: entrepreneurship education from an ecosystem perspective at MIT. Triple Helix, v.5, n. 3, p. 1-20. 2018. Disponível em: https://link.springer.com/article/10.1186/s40604-018-0051-y

RICE, M. P.; FETTERS, M. L.; GREENE, P. G. University-based entrepreneurship ecosystems: a global study of six educational institutions. International Journal of Entrepreneurship and Innovation Management, v. 18, n. 5/6, p. 481-501. 2014. Disponível em: https://www.inderscienceonline.com/doi/abs/10.1504/IJEIM.2014.064722

SANTOS, P. M.; FILHO, R. A. M. Empreendedorismo na incubadora da UFRPE: uma reflexão sobre empresas criadas por iniciativas de alunos e docentes. Organizações em Contexto, v. 10, n. 20, p. 371-406. 2014. Disponível em: https://www.metodista.br/revistas/revistas-metodista/ index.php/OC/article/view/5010/pdf_123

SANTOS-FILHO, L. A.; GUIMARÃES, L. O.; MARTINS, H. C.; PENNA, L. B. Análise da atuação dos domínios políticas públicas e recursos humanos em um ecossistema empreendedor. Revista Economia \& Gestão, v. 19, n. 54, p.1-19. 2019.

SAXENIAN, A. Regional Networks and the resurgence of Silicon Valley. California Management Review. p. 89-109. 1990. Disponível em: http://www1.ximb.ac.in/users/fac/visiting/vfac.nsf/2 3e5e39594c064ee852564ae004fa010/51e213743b63ce6e65257028003e3ccc/\$FILE/saxenian.pdf

SCHUBERT, T.; KROLL, H. Universities' effects on regional GDP and unemployment: the case of Germany. Papers in Regional Science, v. 95, n. 3, p. 467-490. 2016. Disponível em: https:// onlinelibrary.wiley.com/doi/abs/10.1111/pirs.12150 
SERVIÇO BRASILEIRO DE APOIO ÀS MICRO E PEQUENAS EMPRESAS. Empreendedorismo nas universidades brasileiras. 2016. Disponível em: https://m.sebrae.com.br/Sebrae/Portal\%20 Sebrae/Anexos/Relatorio\%20Endeavor\%20impressao.pdf

SHIROKOVA, G.; TSUKANOVA, T.; MORRIS, M. H. The moderating role of national culture in the relationship between university entrepreneurship offerings and student start-up activity: and embeddedness perspective. Journal of Small Business Management, v. 56, n. 1, p. 103-130. 2018.

SILVA, S. A.; BAÊTA, A. M. C.; OLIVEIRA, J. L. Por que analisar a gestão das incubadoras de empresas de base tecnológica sob a ótica da resource-based view? REAd - Revista Eletrônica de Administração, v. 85, n. 3, p. 462-493. 2016.

SPIGEL, B. The relational organization of entrepreneurial ecosystems. Entrepreneurship theory and practice, v. 41, n. 1, p. 49-72. 2015.

STAM, E. Entrepreneurship, Evolution and geography. Papers on Economics \& Evolution, p. 1-24. 2008.

STAM, E.; SPIGEL, B. Entrepreneurial ecosystems. Utrecht School of Economics Discussion Paper Series 16-13, p. 1-18. 2016.

SUDDABY, R.; BRUTON, G. D.; STEVE, X. S. Entrepreneurship through a qualitative lens: insights on the construction and/or discovery of entrepreneurial opportunity. Journal of $B u-$ siness Venturing, v. 30, p. 1-10. 2015.

SUZIGAN, W.; ALBUQUERQUE, E. M. The underestimated role of universities for the Brazilian system of innovation. Brazilian Journal of Political Economy, v. 31, n. 1, p. 3-30. 2011.

TSENG, F.; HUANG, M.; CHEN, D. Factors of university-industry collaboration affecting university innovation performance. Journal of Technology Transfer, p. 1-18. 2018.

TORNATZKY, L. G.; RIDEOUT, E. C. Innovation U 2.0: reinventing university roles in a knowledge economy. 2014. Disponível em: http://www.innovation-u.com/InnovU-2.0_rev-12-14-14.pdf.

VEDOVELLO, C. A.; JUDICE, V. M. M.; MACULAN, A. D. Revisão crítica às abordagens a parques tecnológicos: alternativas interpretativas às experiências brasileiras recentes. $R A I$ Revista de Administração e Inovação, v. 3, n. 2, p. 103-118. 2006.

YIN, R., K. Projetando estudos de caso. In Yin (2005), Estudo de caso: planejamento e método (p. 39-79). Porto Alegre: Bookman. 2005.

WORLD ECONOMIC FORUM. The Global Competitiveness Report 2019. 2019. Disponível em: http://www3.weforum.org/docs/WEF_TheGlobalCompetitivenessReport2019.pdf

Recebido em: 26-02-2021

Aprovado em: 2-12-2021

Avaliado pelo sistema double blind review.

Disponível em http://mjs.metodista.br/index.php/roc 